JPP IPTEK Mei 2018, Vol. 2, No. 1

ISSN 2620-7745 (online)

http://dx.doi.org/10.31284/j.jpp-iptek.2018.v2i1.247

\title{
Pelatihan Pengajaran Bahasa Inggris Usia Dini bagi Guru-Guru Bahasa Inggris di PAUD-TK-MI
}

\author{
Lailatul Masruroh $^{1}$, Maslakhatul Ainiyah $^{2}$, Bariqotul Hidayah ${ }^{3}$ \\ ${ }^{1,2,3}$ Pendidikan Bahasa Inggris, STKIP Qomaruddin Gresik \\ ${ }^{1}$ lailatul.masruroh@stkipqomaruddin.ac.id
}

\begin{abstract}
English, as an international language, gained more attention in education in Indonesia. This foreign language is a compulsory subject in junior high and high school (SMA). And it is a local content in elementary school (SD). Even some study groups $(K B)$ or kindergarten (TK) already teach English to children. Early age is the age at which children acquire or learn something new with ease. This is as per with second language acquisition theory. Therefore, this public service activity is conducted to reduce the errors in early childhood language learning especially related to the teaching techniques and strategies. This activity aims to provide English language teaching training for English teachers in PAUD/TK/MI AbarAbir Village. Overview of teaching English for the young learners is provided to the teachers.
\end{abstract}

Keywords: Training, Teaching, English teacher, English for the young learners

\begin{abstract}
ABSTRAK
Bahasa Inggris, sebagai bahasa internasional, mendapat perhatian lebih dalam dunia pendidikan di Indonesia. Bahasa asing ini dijadikan mata pelajaran wajib di sekolah menengah pertama (SMP) dan sekolah menengah atas (SMA). Selain itu, bahasa ini dijadikan muatan lokal di sekolah dasar (SD). Bahkan, beberapa kelompok belajar (KB) atau taman kanak-kanak (TK) sudah mengajarkan bahasa Inggris untuk anak-anak. Pada usia dini, anak-anak akan dengan mudah memperoleh atau mempelajari sesuatu yang baru, lebih-lebih mempelajari bahasa. Hal ini sesuai dengan teori second language acquisition. Oleh karena itu, untuk mengurangi terjadinya eror pada pembelajaran bahasa di usia dini, khususnya terkait teknik dan strategi pengajaran, kegiatan pengabdian masyarakat ini dilakukan dengan tujuan untuk memberikan pelatihan pengajaran bahasa Inggris usia dini pada guru-guru Bahasa Inggris di PAUD/TK/MI Desa Abar-Abir. Kegiatan ini bertujuan untuk dapat memberikan gambaran kepada guru-guru tentang pengajaran English for the young learner.
\end{abstract}

Kata kunci: Pelatihan, Pengajaran, Guru Bahasa Inggris, Usia dini

\section{PENDAHULUAN}

Bahasa Inggris, sebagai bahasa internasional, mendapat perhatian lebih dalam dunia pendidikan di Indonesia. Bahasa asing ini dijadikan mata pelajaran wajib di sekolah menengah pertama (SMP) dan sekolah menengah atas (SMA). Selain itu, dijadikan muatan lokal di sekolah dasar (SD). Bahkan, beberapa kelompok belajar (KB) atau taman kanak-kanak (TK) sudah mengajarkan bahasa Inggris untuk anak-anak. Hal ini berdampak positif terhadap pencapaian penguasaan bahasa Inggris siswa karena pada dasarnya belajar bahasa harus dimulai sejak dini.

Di sisi lain, muncul isu-isu negatif terkait pengajaran bahasa Inggris bagi anak-anak usia dini. Beberapa guru dirasa kurang kompeten dalam mengajarkan bahasa Inggris, terutama masalah teknik pengajaran. Mereka cenderung mengajarkan bentuk (form) daripada isi (content) pada usia dini. Selain itu, Shin (2000) mengatakan bahwa beberapa guru cenderung mengajarkan kosa kata (vocabulary) secara terpisah atau tidak sesuai dengan konteks penggunaan. Hal ini dirasa tidak efektif dari sisi strategi serta akan menyulitkan siswa saat menggunakan kata tersebut dalam kehidupan sehari-hari sebagaimana yang disampaikan sebagian besar ahli bahasa. Belajar bahasa harus disesuaikan dengan konteks penggunaan kata atau ungkapan yang tepat dan natural.

Pada usia dini, anak-anak akan dengan mudah memperoleh atau mempelajari sesuatu yang baru, lebih-lebih mempelajari bahasa. Hal ini sesuai dengan teori second language acquisition (Chomsky, 1999). Oleh karena itu, untuk mengurangi terjadinya eror pada pembelajaran bahasa di 
usia dini, khususnya terkait teknik dan strategi pengajaran, kegiatan pengabdian masyarakat ini dilakukan dengan tujuan untuk memberikan pelatihan pengajaran bahasa Inggris usia dini pada guru-guru bahasa Inggris di PAUD/TK/MI Desa Abar-Abir.

\section{METODE PELAKSANAAN}

Dalam melaksanakan kegiatan pengabdian kepada masyarakat, tentunya ada beberapa hal yang harus disiapkan dan dilaksanakan. Metode kegiatan pengabdian kepada masyarakat yang dilakukan sebagai berikut.

1) Metode ceramah. Metode ini dilakukan untuk memberi penjelasan tentang pentingnya pembelajaran pronuncation untuk anak. Tim pengabdi menyiapkan beberapa materi dan menjadikannya sebagai bahan powerpoint. Tim pengabdi kemudian memberikan penjelasan dengan menggunakan media proyektor sehingga peserta bisa paham dan memperhatikan titik materi yang dijelaskan.

2) Metode praktik untuk mengajar vocabulary pada young learner. Selain memberikan penjelasan melalui ceramah dan memberikan materi, tim pengabdi juga tidak enggan memberikan beberapa contoh bagaimana mengajar yang baik dan benar dengan menggunakan dan menerapkan pengetahuan English for young learner sehingga guru bisa masuk ke dalam dunia anak dengan berbahasa Inggris yang baik dan benar. Selain itu, materi juga akan bisa masuk ke anak dengan mudah dan menyenangkan.

3) Metode tanya jawab dan diskusi. Setelah sesi pemberian materi dan praktik, tim pengabdi juga memberikan kesempatan tanya jawab kepada peserta. Pada kali ini ada dua alisesi yang masing-masing sesi terdiri dari tiga penanya.

\section{HASIL DAN PEMBAHASAN}

Hasil pengabdian kepada masyarakat yang dilaksanakan dengan cara tatap muka dan praktik pengajaran menggunakan joyful learning berjalan dengan baik dan lancar. Pertemuan tatap muka dilakukan dengan metode ceramah dan demonstrasi (Gambar 1), dilanjutkan dengan praktik/latihan mengajar dengan menggunakan gambar dan alat peraga yang lain (Gambar 2), media yang menarik, mulai dari pemilihan materi, pemilihan gambar, dan pemaduan antara keduanya dalam pembelajaran. Kegiatan ini dilaksanakan dalam sehari yaitu pada Rabu, 19 Februari 2018 pukul 08.00-13.30 WIB. Peserta kegiatan berjumlah 26 orang guru tingkat dasar dan menengah. Sebagian besar peserta pelatihan ini adalah guru sekolah post-PAUD, PAUD, TK, SD/MI yang mayoritas bukan lulusan atau sarjana Pendidikan Bahasa Inggris.

Pelaksanaan kegiatan pengabdian masyarakat ini dilakukan oleh lima orang tim pengabdi dengan pokok bahasan yang disampaikan mengenai

1) metode pembelajaran vocabulary dengan multisensory technical kepada anak usia dini (Kasiani, 2012);

2) metode pembelajaran joyful learning (Cameron, 2002);

3) pengajaran menggunakan game dan picture dalam pembelajaran Bahasa Inggris; serta

4) evaluasi hasil pembelajaran yang telah dilaksanakan, keterbatasan waktu pertemuan mengakibatkan tidak semua materi dapat disampaikan dengan gamblang.

Kegiatan yang diawali dengan ceramah dan demostrasi ini kemudian dilanjutkan dengan latihan. Berdasarkan kegiatan latihan, tampak bahwa guru memang belum menguasai cara pelafalan bahasa Inggris yang baik dan benar. Banyak alasan yang disampaikan oleh guru-guru terkait hambatan dalam pembelajaran pada young learner. Para guru mengeluhkan kurangnya pengalaman dan pengetahuan tentang metode dan konsep pengajaran bahasa Inggris pada young learner. Kebanyakan dari mereka bukan sarjana atau lulusan Pendidikan Bahasa Inggris. 


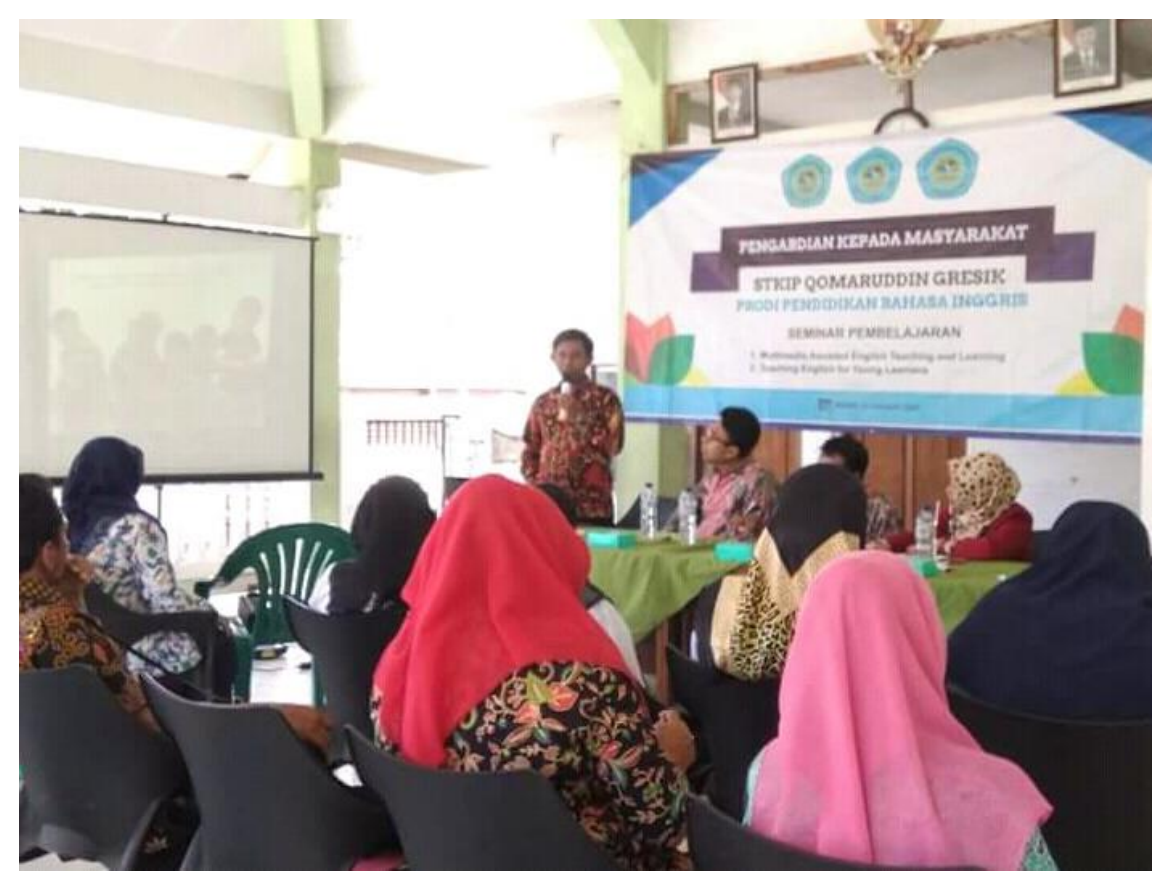

Gambar 1. Foto Kegiatan Metode Ceramah

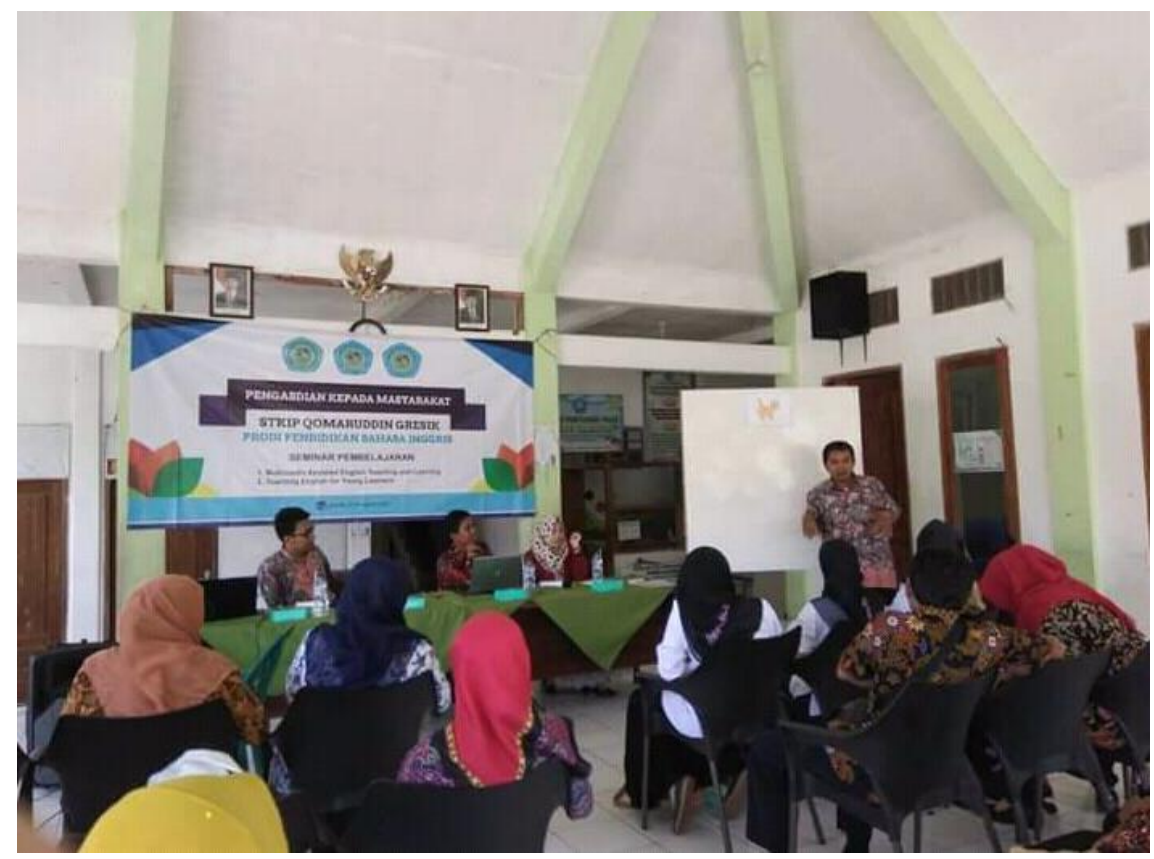

Gambar 2. Metode Menggunakan Media Gambar

Sesi terakhir dalam acara ini adalah tanya jawab. Berbagai pertanyaan diajukan dengan antusias. Secara garis besar, inti pertanyaan para peserta adalah mengenai

1) metode pengajaran yang baik untuk anak usia dini;

2) teknik mengajarkan vocabulary dan pronunciation kepada anak usia dini; serta

3) langkah-langkah pengajaran menggunakan game and picture sehingga hasil pelatihan ini akan bermanfaat dan menambah kualitas dalam pembelajaran bagi sekolah, karena penggunaan game dan picture membawa para guru masuk ke dunia anak-anak kembali. Belajar terasa lebih menarik dan menyenangkan. Selain itu, adanya pelatihan ini membuat keterampilan guru akan meningkat, baik dalam pengajaran maupun dalam kedekatan dengan siswa. 


\section{KESIMPULAN}

Kegiatan ini sangat membantu guru dalam meningkatkan pengetahuan dan kemampuan dalam mengajar Bahasa Inggris di tingkat anak-anak dengan memanfaatkan media picture dan game.

\section{DAFTAR PUSTAKA}

Cameron, L. (2002). Teaching Languages to Young Learners. Cambridge University Press.

Chomsky, N. (1999). On Nature, Use, and Acquisition of Language. Dalam Ritchie dan Bhatia.

Kasiani, S. (2012). Teaching English for Young Learners. Jakarta: Bumi Aksara.

Shin, J. K. (2000). Teaching English to Young Learners. University of Maryland, Baltimore County. 